\title{
Sex Difference in Lactate Production by Adipocytes from Lean Humans
}

\author{
Danilo Roberto X. de O. Crege1, Henrique José V. Silveira², Élinton Adami Chaim², \\ José Carlos Pareja ${ }^{2}$, Alain Géloen ${ }^{3}$, Dora Maria Grassi-Kassisse ${ }^{1^{*}}$ \\ ${ }^{1}$ Department of Structural and Functional Biology, Institute of Biology, University of Campinas (UNICAMP), \\ Campinas, São Paulo, Brazil \\ ${ }^{2}$ Department of Gastroenterology, School of Medical Sciences, University of Campinas (UNICAMP), \\ Campinas, São Paulo, Brazil \\ ${ }^{3}$ Hospices Civils de Lyon, Université de Lyon, Lyon, France \\ Email: ${ }^{*}$ doramgk@unicamp.br
}

Received 22 January 2014; revised 22 February 2014; accepted 1 March 2014

Copyright (C) 2014 by authors and Scientific Research Publishing Inc.

This work is licensed under the Creative Commons Attribution International License (CC BY).

http://creativecommons.org/licenses/by/4.0/

(c) (i) Open Access

\section{Abstract}

Lactate is an anaerobic metabolite produced in the absence of an adequate $\mathrm{O}_{2}$ supply. Although for a long time considered to be a waste product of glycolysis resulting from hypoxia, lactate is, in fact, an important source of glucose and also a gluconeogenic precursor, having a role in metabolic and endocrine signaling. Lactate is produced by adipocytes and muscle cells. Objectives: In this study, we investigated the sex differences in lactate production by adipocytes isolated from lean human visceral adipose tissue. Main Methods: The experiments described were done using adipocytes isolated from adipose tissue of lean men and women. Adipocytes were isolated following Rodbell procedure, with modifications, for posterior analysis of glycerol and lactate production. Results: Morphometric analysis revealed no significant differences in the size of adipocytes from men and women (diameter: men: $172 \pm 24 \mu \mathrm{m}$ vs. women: $160 \pm 16 \mu \mathrm{m}, \mathrm{n}=4$ and 10, respectively). Basal glycerol production was significantly higher in adipocytes from men compared to women $\left(0.34 \pm 0.06\right.$ vs. $0.16 \pm 0.01 \mu \mathrm{mol} / 10^{6}$ cells $/ 60$ min; mean $\pm S E M, n=7$ and 4 , respectively; $p<0.05$ ), but there was no significant difference in basal lactate production (men: $0.1 \pm$ $0.01 \mu \mathrm{mol} / 10$ cells $/ 60 \mathrm{~min}$ vs. women: $0.12 \pm 0.02 \mu \mathrm{mol} / 10$ cells $/ 60 \mathrm{~min}$ ). However, when stimulated by norepinephrine, adipocytes from women produced more lactate than adipocytes from men. Female adipocytes also produced as much lactate as glycerol, whereas male adipocytes produced three times more glycerol than lactate. The intracellular mechanisms responsible for this sex difference in lactate production during norepinephrine-stimulated lipolysis remain to be identified.

\footnotetext{
"Corresponding author.
} 


\section{Keywords}

\section{Adipose Tissue; Glycerol; Humans; Lactate; Lipolysis}

\section{Introduction}

Lipolysis in white adipose cells is mainly under adrenergic control, and the effects of catecholamines are mediated by four G-protein-coupled adrenergic receptor (AR) subtypes. The $\beta$-adrenergic receptors $\left(\beta_{1}, \beta_{2}\right.$ and $\left.\beta_{3}\right)$ stimulate lipolysis by increasing the formation of cyclic AMP (cAMP), which leads to the stimulation of protein kinase A (PKA) and the phosphorylation of hormone-sensitive lipase (HSL) and perilipin protein. In contrast, the $\alpha_{2}$-adrenergic subtype inhibits lipolysis by decreasing cAMP formation. Thus, the net effect of catecholamines on adipose tissue depends on the functional balance between $\beta$ - and $\alpha_{2}$-adrenergic-mediated signal transduction [1].

The physiological importance of $\beta$ - and $\alpha_{2}$-adrenoceptors in animals and humans varies with species, sex, age,

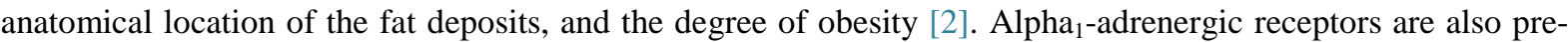
sent in rat white adipose cells at a concentration ranging from 9 - $12 \mathrm{fmol} / \mathrm{mg}$ protein [3] to $34 \mathrm{fmol} / \mathrm{mg}$ protein [4]. These receptors are not involved in lipolysis, but they mediate the stimulation of glucose uptake and lactate production in rat white adipocytes [5] [6]. Similar findings have been reported for humans, where the stimulation of $\alpha_{1}$-adrenoreceptors by phenylephrine in abdominal adipose tissue leads to an increase in glucose uptake and lactate production [7]. As norepinephrine is a full $\alpha_{1} / \alpha_{2}$ - and $\beta$-adrenergic agonist, this means that free fatty acids, glycerol and lactate are produced during lipolysis.

Marked differences in the amount and distribution of body fat between men and women provide clear evidence of sex-related differences in the whole body lipid metabolism [8]-[10]. In women, a greater amount of fat is stored in the lower body regions, whereas in men most fat is stored in the upper body. Women store greater amounts of fat subcutaneously, whereas fat storage in men occurs around the organs in the abdominal cavity [10] [11]. Variations in the lipolytic activity are also sex-dependent [7]. However, sex differences in lactate production by adipocytes have not been studied yet. The aim of this study was to compare the basal and norepinephrine stimulated lactate production by adipocytes isolated from lean men and women.

\section{Methodology}

\subsection{Subjects}

The experiments described here were done using adipocytes isolated from adipose tissue of lean men and women who were closely matched for age (46 \pm 4.5 and $49 \pm 6.1$ years old, respectively) and body mass index (21.7 \pm 0.61 and $22.1 \pm 1.1$, respectively). This study was approved by the Ethics Committee of the School of Medical Sciences, at UNICAMP (Protocol number 097/2003).

\subsection{Adipocyte Isolation, Counting and Morphometric Cell Measurements}

Visceral adipose tissue was collected during gastric surgery, and the adipocytes were isolated from visceral fat pads as described by [12], but with slight modifications. Three grams of adipose tissue were weighed, minced and digested in $50 \mathrm{~mL}$ polyethylene vials containing $10 \mathrm{~mL}$ of Krebs-Ringer bicarbonate buffer, $25 \mathrm{mM}$ HEPES, $6 \mathrm{mM}$ glucose $\mathrm{pH} 7.4$ (KRB buffer) with $1 \mathrm{mg}$ of collagenase/mL (type 2, Clostridium histoliticum), 1\% bovine serum albumin (BSA, fraction 5, fatty acid-free) and $200 \mathrm{nM}$ adenosine. The vials were incubated at $37^{\circ} \mathrm{C}$ with shaking (60 cycles/min) for $45 \mathrm{~min}$. The resulting cell suspension was filtered through a nylon mesh and washed three times with $5 \mathrm{~mL}$ of fresh KRB buffer containing 4\% BSA (KRBA). After isolation, a $100 \mu \mathrm{L}$ aliquot of cell suspension was diluted in $900 \mu \mathrm{L}$ of KRBA, and $10 \mu \mathrm{L}$ of the diluted suspension was transferred to a Mallassez chamber to count the number of adipocytes. The assays described below were done using 50,000 or 100,000 cells $/ \mu \mathrm{L}$, and all of the results were expressed per million cells [13]. Morphometric analysis was conducted as described by [14]. Briefly, a $10 \mu \mathrm{L}$ aliquot of cell suspension (approximately $10^{5}$ cells/mL) was placed in a Mallassez chamber for light microscopy and image analysis. Adipocyte size (diameter) was analyzed with 
Image Pro Plus software v 3.0 (Media Cybernetics, Silver Spring, MD). For each slide, four images were captured and all of the cells present in the field were analyzed. The results were expressed as the mean \pm SEM $(\mu \mathrm{m})$.

\subsection{Adipocyte Incubation}

Aliquots of adipocyte suspension were pipetted into polyethylene vials containing fresh buffer and different concentrations of norepinephrine (from $0.001 \mu \mathrm{M}$ to $1 \mu \mathrm{M}$ ) in a final volume of $1 \mathrm{~mL}$, followed by incubation at $37^{\circ} \mathrm{C}$ with shaking (60 cycles/min) for $60 \mathrm{~min}$. At the end of the incubation, the vials were placed in melting ice, and the adipocytes were removed from the vials by aspiration. Basal lipolysis was determined in adipocytes incubated without norepinephrine.

\subsection{Glycerol Determination}

Glycerol production was measured using coupled enzyme reactions catalyzed by glycerol kinase, glycerol phosphate oxidase and peroxidase. Glycerol was phosphorylated by adenosine triphosphate (ATP) to produce glycerol-1-phosphate and ADP in a reaction catalyzed by glycerol kinase. Glycerol-1-phosphate was then oxidized by glycerol phosphate oxidase to dihydroxyacetone phosphate and hydrogen peroxide. A quinoneimine dye was produced by the peroxidase-catalyzed coupling of 4-amonoantipyrine (4-AAP) and sodium N-ethyl-N(3-sulfopropyl)-m-anisidine (ESPA) with hydrogen peroxide, which shows an absorbance maximum at $540 \mathrm{~nm}$ [15]. All quantifications were done using commercial kits from Laborlab ${ }^{\circledR}$ (São Paulo, SP, Brazil).

\subsection{Lactate Determination}

Lactate was quantified in a reaction catalyzed by lactate oxidase that yielded pyruvate and hydrogen peroxide $\left(\mathrm{H}_{2} \mathrm{O}_{2}\right)$. In the presence of $\mathrm{H}_{2} \mathrm{O}_{2}$, peroxidase catalyzed the oxidative condensation of chromogen precursors to produce a dye with an absorbance maximum at $540 \mathrm{~nm}$ [15]. All quantifications were done using commercial kits from Trinity ${ }^{\circledR}$ (Wicklow, Ireland).

\subsection{Statistical Analysis}

The results are presented as the mean \pm SEM. Statistical comparisons were done using Student's t-test with $\mathrm{p}<$ 0.05, considered significant. All curve fitting and statistical analyses were done using Prism software (GraphPad Inc., La Jolla, CA).

\section{Results}

We have previously shown that there is no sex difference in the fasting plasma glucose (men: $5.1 \pm 0.2 \mathrm{mmol} / \mathrm{L}$ vs. women: $4.7 \pm 0.1 \mathrm{mmol} / \mathrm{L}$; mean $\pm \mathrm{SEM}$; $\mathrm{n}=3$ ), insulin (men: $10 \pm 1 \mu \mathrm{U} / \mathrm{mL}$ vs. women: $10 \pm 1 \mu \mathrm{U} / \mathrm{mL}, \mathrm{n}=$ 3) and lactate (men: $1154 \pm 113 \mu \mathrm{M}$ vs. women: $912 \pm 305 \mu \mathrm{M}, \mathrm{n}=3$ ) concentrations, or in the insulin sensitivity HOMA index, i.e., ([glucose] × [insulin])/22.5 (men: $2.29 \pm 0.14$ vs. women: $2.34 \pm 0.19$, n = 3) [16]

The values of the morphometric analysis from isolated adipocytes of eutrophic men and women were not different between genders sexes, men: $172 \pm 24 \mu \mathrm{m}$ vs. women: $160 \pm 16 \mu \mathrm{m}, \mathrm{n}=4$ and 10, respectively (Figure 1).

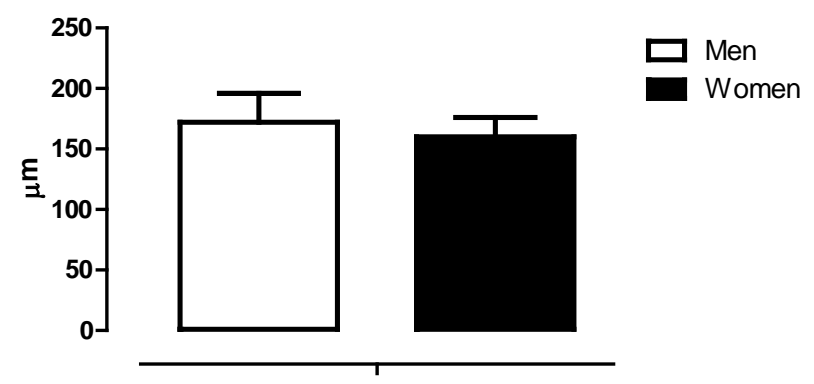

Figure 1. Morphometric values for isolated adipocytes of lean men $(n=4)$ and women $(n=10)$. 
The lipolytic response of white adipocytes stimulated with norepinephrine was minor in women than in men (Figure 2(a)), and the area under the curve (AUC) of the lipolytic response to norepinephrine was significantly lower in women than in men (Figure 2(b)). In contrast, lactate production was slightly higher in adipocytes from women than from men (Figure 2(c)). Although there were no marked differences between the sexes at any given concentration of norepinephrine, the AUC for lactate production was but significantly higher in than in men (Figure 2(d)).

During lipolysis, adipocytes from men produced more glycerol per molecule than did the adipocytes from women did, and. This was reflected in the glycerol/lactate ratio, which was $\sim 1$ in women and close to 3 in adipose cells from men (Figures 2(e) and (f)). These ratios were constant in both groups, regardless of the norepinephrine concentration.

\section{Discussion}

The stimulation of adipocytes by norepinephrine results in simultaneous lipolysis and lactate production. As shown here, adipocytes from women produced more lactate than the adipocytes from men (Figure 2(d)). Female

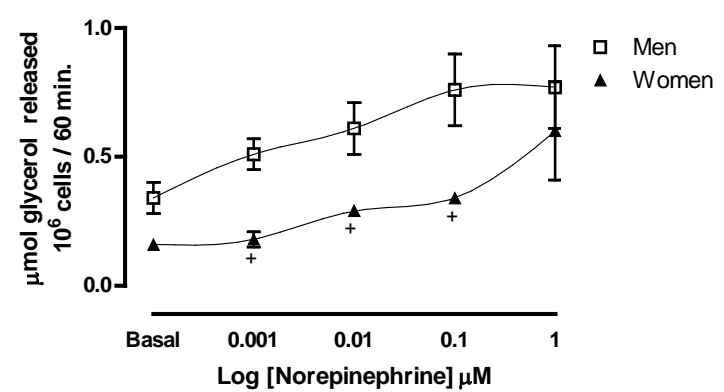

(a)

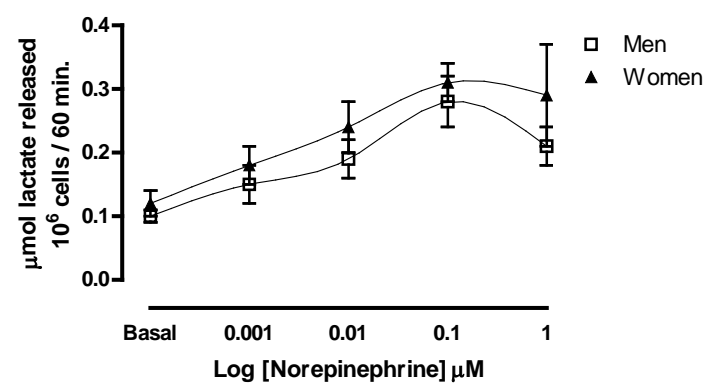

(c)

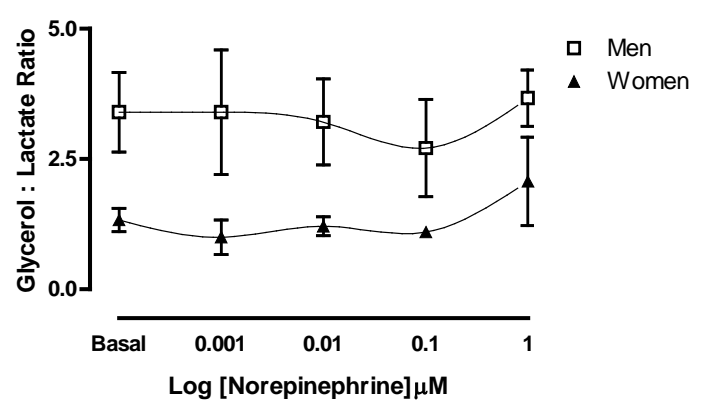

(e)

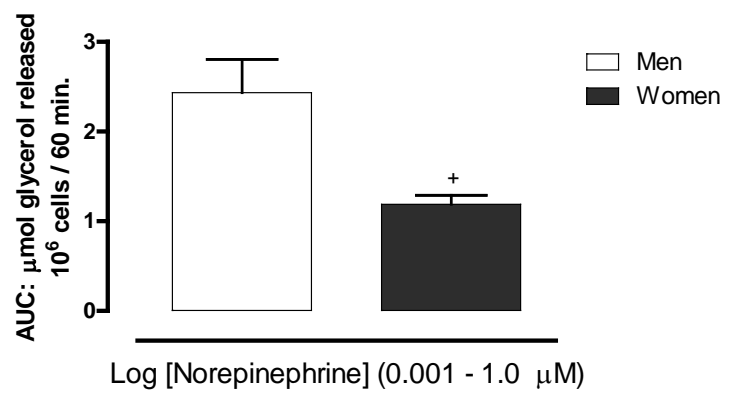

(b)

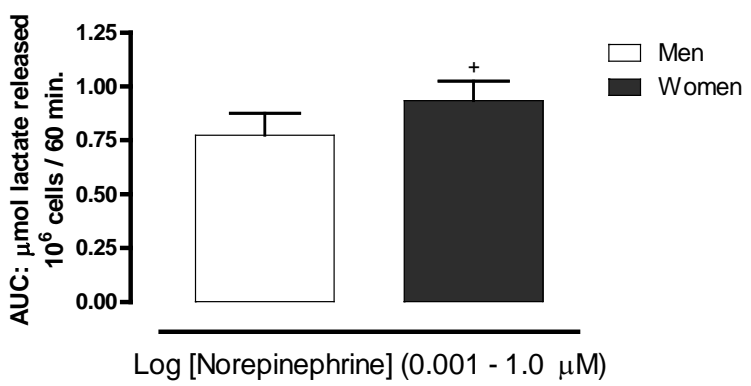

(d)

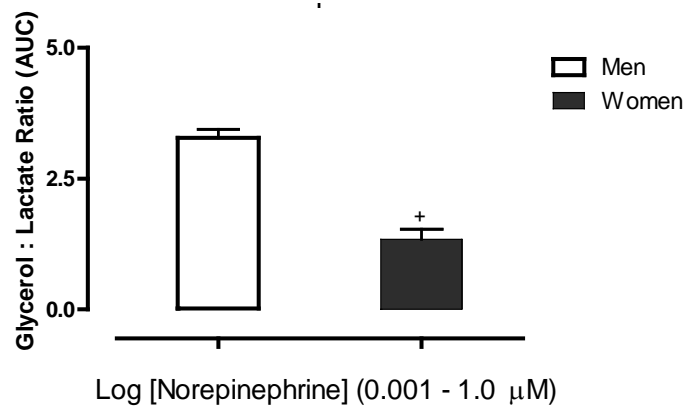

(f)

Figure 2. Glycerol and lactate production by adipocytes from men and women stimulated or not with norepinephrine. (a) Glycerol production by adipocytes men and women. (b) Area under curve for glycerol production by adipocytes from men and women. (c) Lactate production by adipocytes from men and women. (d) Area under curve for lactate production by adipocytes from men and women. (e) Glycerol/Lactate production ratio by adipocytes from men and women. (f) Area under curve for glycerol/lactate production ratio by men and women adipocytes. 
adipocytes also produced as much lactate as glycerol, whereas male adipocytes produced three times more glycerol than lactate (Figures 2(e), (f)). Most of the difference observed between men and women was related to the decreased lipolytic response in female adipocytes (Figure 2(a)). Such a sex difference has already been observed in visceral fat lipolysis and metabolic complications associated with obesity [1]. We observed greater glycerol production in adipocytes from men compared to women, a finding in agreement with previous reports [17] [18]. Lönnqvist et al. [1], for instance, found no sex-related differences in the lipolytic sensitivity of male and female adipocytes to $\alpha_{1}$ - or $\alpha_{2}$-adrenoceptor agonists or in the antilipolytic effect of insulin. However, nevertheless, the $\alpha_{3}$-adrenoceptor lipolytic sensitivity was 12 times higher and the $\alpha_{2}$-adrenoceptor antilipolytic sensitivity was 17 times lower in adipocytes from men compared to women. Lipolysis induced by agents acting on adenylate cyclase and PKA was almost two-fold greater in adipocytes from men compared to women, even though there existed no difference in the maximum hormone-sensitive lipase activity. Lönnqvist et al. [1] concluded that sex-related differences in lipolysis were not only partly attributable to a greater fat cell volume in men, but also to a decrease in $\alpha_{2}$-adrenoceptor activity, an increase in $\alpha_{3}$-adrenoceptor activity and a greater ability of cAMP to activate hormone-sensitive lipase.

Lactate has also recently been shown to mediate the inhibition of lipolysis by GPR81 [19]. Although the difference in lactate production by adipocytes from men and women were significantly higher, it may nevertheless be enough to significantly inhibit lipolysis in female adipocytes. It is still unclear whether the expression of GPR81 is significantly different in adipose cells of men and women.

Sargent et al. [20] reported that the plasma lactate concentration was significantly lower in women than in men during incremental cycle ergometer exercise at all relative intensities between $30 \%$ and $100 \%$ of the oxygen consumption peak. Plasma lactate reaches higher concentrations in men than in women during exercise [21]. Although the basis for this difference is unknown, our results suggest that it is unrelated to the glycerol/lactate ratio in male and female adipocytes during lipolysis.

The simultaneous production of glycerol and lactate, observed here in response to norepinephrine, indicates that the adipocyte $\alpha_{1}$-adrenoreceptors are fully functional. These receptors are not involved in lipolysis, yet they stimulate glucose uptake and lactate production by adipocytes [6] [13], indicating that there is a specific receptor associated with lactate production in these cells.

Lactate is an anaerobic metabolite produced in the absence of an adequate $\mathrm{O}_{2}$ supply. Although for a long time considered to be a waste product of glycolysis resulting from hypoxia [22], lactate is, in fact, an important source of glucose and also a gluconeogenic precursor [23] with a role in metabolic and endocrine signaling. Indeed, the infusion of exogenous lactate effectively attenuates the sympathetic response to exercise [24]. In retinal vasculature, lactate has a dual vasoactive action by affecting the contractility of pericytes [25]. Despite these known functions, the physiological relevance of lactate production by adipocytes remains still unclear.

\section{Conclusion}

In sum, our results show that adipocytes produce lactate during lipolysis and that there is a small but significant difference in lactate production by adipocytes from men and women. During lipolysis, the ratio glycerol/lactate is close to one in adipocytes isolated from lean women, while it is approximately close to 3 for adipocytes isolated from lean men. The reason of such a difference is yet unknown, and a higher density of alpha ${ }_{1}$-adrenergic receptors in adipocytes from women could partly explain that difference. This finding indicates that adipose tissue is involved in the lactate shuttle proposed by Brooks [26] [27]. However, the intracellular mechanisms responsible for this sex difference in lactate production during lipolysis remain to be identified.

\section{Acknowledgements}

This study was supported by grants from the National Council for Scientific and Technological Development (CNPq) and the São Paulo Research Foundation (FAPESP). We thank Espaço da Escrita—Coordenadoria Geral da Universidade-UNICAMP_for the text revision.

\section{References}

[1] Lönnqvist, F., Thörne, A., Large, V. and Arner, P. (1997) Sex Differences in Visceral Fat Lipolysis and Metabolic Complications of Obesity. Arteriosclerosis, Thrombosis, and Vascular Biology, 17, 1472-1480. 
http://dx.doi.org/10.1161/01.ATV.17.7.1472

[2] Lafontan, M. and Berlan, M. (2003) Do Regional Differences in Adipocyte Biology Provide New Pathophysiological Insights? TIPS, 24, 276-83. http://dx.doi.org/10.1016/S0165-6147(03)00132-9

[3] Torres-Marques, E., Romero-Avila, M.T., Gonzales-Espinosa, C. and Garcia-Sainz, A. (1992) Characterization of White Fat Cell Alpha1 ${ }_{b}$-Adrenoceptors. Molecular Pharmacology, 42, 403-406.

[4] Kobatake, T., Watanabe, Y., Matsuzawa, Y., Tokunaga, K., Fujioka, S., Kawamoto, T., Keno, Y., Tarui, S. and Yoshida, H. (1991) Age-Related Changes in Adrenergic Alpha , Alpha $_{2}$, and Beta Receptors of Rat White Fat Cell Membranes: An Analysis Using [3H]Bunazosin as a Novel Ligand for the Alpha 1 Adrenoceptor. The Journal of Lipid Research, 32, 191-196.

[5] Faintrenie, G. and Géloën, A. (1996a) Lactate Production by White Adipocytes in Relation to Insulin Sensitivity. American Journal of Physiology, 270, C1061-1066.

[6] Faintrenie, G. and Géloën, A. (1998) Alpha-1 Adrenergic Stimulation of Glucose Uptake in Rat White Adipocytes. Journal of Pharmacology and Experimental Therapeutics, 286, 607-610.

[7] Boschmann, M., Gotz, K., Friedrich, CL., Klaus, S. and Jordan, J. (2002). In Vivo Response to $\alpha_{1}$-Adrenoceptor Stimulation in Human White Adipose Tissue. Obesity Research, 10, 555-558. http://dx.doi.org/10.1038/oby.2002.75

[8] Bjorntorp, P. (1985) Regional Patterns of Fat Distribution. Annals of Internal Medicine, 103, 994-995. http://dx.doi.org/10.7326/0003-4819-103-6-994

[9] Ley, C.J., Less, B. and Stevenson, J.C. (1992) Sex and Menopause Associated Changes in Body Fat Distribution. American Journal of Clinical Nutrition, 55, 950-954.

[10] Blaak, E. (2001) Gender Differences in Fat Metabolism. Current Opinion in Clinical Nutrition \& Metabolic Care, 4, 499-502. http://dx.doi.org/10.1097/00075197-200111000-00006

[11] Kotani, K., Tokunaga, K., Fujioka, S., Kobatake, T., Keno, Y., Yoshida, S., Shimomura, I., Tarui, S. and Matsuzaw, Y. (1994) Sexual Dimorphism of age-related changes in Whole Body Fat Distribution in the Obese. Int J Obesity Related Metabolic Disorders, 18, 207-212.

[12] Rodbell, M. (1964) Metabolism of Isolated Fat Cells-Effects of Hormones on Glucose Metabolism and Lipolysis. Journal of Biological Chemistry, 239, 375-380.

[13] Faintrenie, G. and Géloën, A. (1996b) Alpha-1 Adrenergic Regulation of Lactate Production by White Adipocytes. Journal of Pharmacology and Experimental Therapeutics, 277, 235-238.

[14] Salerno, A.G., Silva, T.R., Amaral, M.E., Alberici, L.C., Bonfleur, M.L., Patrício, P.R., Francesconi, E.P.M.S., Grassi-Kassisse, D.M., Vercesi, A.E., Boschero, A.C. and Oliveira, H.C. (2007) Overexpression of Apolipoprotein CIII Increases and CETP Reverses Diet-Induced Obesity in Transgenic Mice. International Journal of Obesity, 31, 1586-1595. http://dx.doi.org/10.1038/sj.ijo.0803646

[15] Barhan, D. and Trinder, P, (1972) An Improved Colour Reagent for Determination of Glucose by the Oxydase System. Analyst, 97, 142. http://dx.doi.org/10.1039/an9729700142

[16] Francesconi, E.P.M.S., Almeida, J., Marin, D.M., Ortiz, J., Pareja, J.C., Muscelli, E., Monte-Alegre, S., Geloneze, B., Silveira, H.V., Spadari-Bratfisch, R.C., Géloën, A. and Grassi-Kassisse, D.M. (2006) Plasmatic Lactate Levels in Normal and Morbidly Obese Women before and during Euglicemic-Hyperinsulinemic Clamp. 41st Congress of the Brazilian Physiological Society \& Joint Meeting with the Physiological Society, 237.

[17] Rebuffé-Scrive, M., Anderson, B., Olbe, L. and Bjorntorp, P. (1989) Metabolism of Adipose Tissue in Intraabdominal Depots of Nonobese Men and Women. Metabolism, 38, 453-458. http://dx.doi.org/10.1016/0026-0495(89)90198-4

[18] Williams, C.M. (2004) Lipid Metabolism in Women. Proceedings of the Nutrition Society, 63, 153-160. http://dx.doi.org/10.1079/PNS2003314

[19] Ahmed, K., Tunaru, S., Tang, C., Müller, M., Gille, A., Sassmann, A., Hanson, J. and Offermanns, S. (2010) An Autocrine Lactate Loop Mediates Insulin-Dependent Inhibition of Lipolysis through GPR81. Cell Metabolism, 11, 311-319. http://dx.doi.org/10.1016/j.cmet.2010.02.012

[20] Sargent, C. and Scroop, G.C. (2007) Plasma Lactate Accumulation Is Reduced during Incremental Exercise in Untrained Women Compared with Untrained Men. European Journal of Applied Physiology, 101, 91-96. http://dx.doi.org/10.1007/s00421-007-0477-9

[21] Esbjörnsson, M., Norman, B., Suchdev, S., Viru, M., Lindhgren, A. and Jansson, E. (2009) Greater Growth Hormone and Insulin Response in Women Than in Men during Repeated Bouts of Sprint Exercise. Acta Physiologica, 197, 107-115. http://dx.doi.org/10.1111/j.1748-1716.2009.01994.x

[22] Gladden, L.B. (2004) Lactate Metabolism: A New Paradigm for the Third Millennium. The Journal of Physiology, 558, 5-30. http://dx.doi.org/10.1113/jphysiol.2003.058701

[23] Miller, B.F., Fattor, J.A., Jacobs, K.A., Horning, M.A., Navazio, F., Lindinger, M.I. and Brooks, G.A. (2002) Lactate 
and Glucose Interactions during Rest and Exercise in Men: Effect of Exogenous Lactate Infusion. The Journal of Physiology, 544, 963-975. http://dx.doi.org/10.1113/jphysiol.2002.027128

[24] Fattor, J.A., Miller, B.F., Jacobs, K.A. and Brooks, G.A. (2005) Catecholamine Response Is Attenuated during Moderate-Intensity Exercise in Response to the "Lactate Clamp”. American Journal of Physiology: Endocrinology and Metabolism, 288, E143-147. http://dx.doi.org/10.1152/ajpendo.00117.2004

[25] Yamanishi, S., Katsumura, K., Kobayashi, T. and Puro, D.G. (2006) Extracellular Lactate as a Dynamic Vasoactive Signal in the Rat Retinal Microvasculature. Heart and Circulatory Physiology-American Journal of Physiology, 290, H925-934. http://dx.doi.org/10.1152/ajpheart.01012.2005

[26] Brooks, G.A. (2000) Intra- and Extra-Cellular Lactate Shuttles. Medicine \& Science in Sports \& Exercise, 32, $790-799$. http://dx.doi.org/10.1097/00005768-200004000-00011

[27] Brooks, G.A. (2009) Cell-Cell and Intracellular Lactate Shuttles. The Journal of Physiology, 587, 591-600. 